\title{
The Mid-Ventral Gland of the Indian Desert Gerbil
}

\author{
Saroj KUMARI, P. E. COWAN ${ }^{1} \&$ Ishwar PRAKASH
}

\begin{abstract}
Kumari S., Cowan P. E. \& Prakash I., 1981: The mid-ventral gland of the Indian desert gerbil. Acta theriol., 26, 6: 97-106 [With 2 Tables, 3 Figs. \& Plate III]

Histological structure of the mid-ventral gland and its role in scent marking were studied in the Indian desert gerbil, Meriones hurrianae. The gland comprises complexes of enlarged sebaceous alveoli of the typical holocrine type, each with its own duct. The holocrine secretion collects in large common ducts whence it is deposited on objects by the gerbil with a characteristic ventral rubbing action. Only adult gerbils had visibly secreting glands. Gland size was correlated with body weight and head and body length. Males had larger glands than females, both in absoiute size and relative to their body size and weight. Male gerbils made many more scent marks using the midventral gland than did females. Social interactions between gerbils stimulated marking by the dominant gerbil but totally suppressed marking by the defeated gerbil.

[Coordinating and Monitoring Centre for Rodent Research and Training, CAZRI, Jodhpur, India].
\end{abstract}

\section{INTRODUCTION}

Many species of gerbil, Meriones, have a distinct midabdominal sebaceous gland complex, larger in males than in females (Sokolov \& Skurat, 1966; Thiessen \& Yahr, 1977). Gerbils rub the secretion from these "scent glands" on objects as they move about their home range (Thiessen \& Yahr, 1977). Only the gland of the Mongolian gerbil, M. unguiculatus, has been examined in detail (Glenn \& Gray, 1965; Mitchell, 1965).

The Indian desert gerbil, Meriones hurrianae (Jerdon, 1867), causes serious damage to natural grasslands by eating seeds and burrowing (Prakash, 1973; Prakash et al., 1969). As part of a programme of research into methods of control, we are investigating the mid-ventral scent gland of this species as a possible source of attractants. The present paper describes gland morphology and histology, and brief behavioural cbservations on scent gland use by laboratory and free-living gerbils.

\section{MATERIALS \& METHODS}

Eighty gerbils of each sex were collected from typical desert habitat in the Thar desert near Jodhpur (Prakash, 1975). They were weighed to $1 \mathrm{~g}$, and head

1 Ecology Division, DSIRO, Lower Hutt, New Zealand.

7-Acta Theriologica

[97] 
and body lengths were measured to $1 \mathrm{~mm}$. Reproductive condition was also recorded. The maximum external length and breadth of mid-ventral glands were measured to $0.1 \mathrm{~mm}$ with vernier callipers.

For histological studies hair was shaved from around the glands of freshly xilled gerbils, and the area was flooded with fixative. The glandular area and surrounding skin were excised and fixed between two thin pieces of glass to prevent curling. Glands were fixed for at least $48 \mathrm{~h}$ in neutral buffered formalin or Bouin's solution. Transverse, longitudinal and sagittal sections were cut at 5-10 mu, stained with haematoxylin and eosin, and mounted in Depex or Canada balsam.

The use of the mid-ventral gland by gerbils to mark objects and places was studied in the laboratory in a glass-fronted wooden observation cage $(46 \times 31 \times 31 \mathrm{~cm})$ containing two white-painted $25 \mathrm{~mm}$ aiuminium cubes. Tests lasted $30 \mathrm{~min}$. and were conducted between 14.00 and $16.00 \mathrm{~h}$. The frequency with the cubes and other parts of the cage were marked was recorded. Encounters lasting $15 \mathrm{~min}$. were then staged between males, between females, and between males and females. Field observations of marking behaviour were made on small colonies of gerbils in wasteland in the grounds of the Central Arid Zone Research Institute Research Farm.

\section{RESULTS}

\section{General}

The scent gland of $M$. hurrianae is present in both sexes prominently situated on the mid-ventral abdominal surface. The gland is generally ovoid in shape and broader anteriorly in males, but of more elongate shape in females. The gland pad can be readily seen by pushing aside the overlying lateral hairs. The yellowish waxy secretion on the gland surface feels oily and has a distinctive sweet, musky smell. When the secretion is removed with chloroform, the gland has a multipore appearance. Groups of short backward-pointing hairs emerge from the pores, particularly towards the edges of the gland pad.

\section{Histology}

The mid-ventral gland consists of complexes of enlarged sebaceous a'lveoli of the typical holocrine type, each with its own duct (Fig. 1, $a-c$, Plate III). The gland differs from the adjoining ventral skin in the greater size of the sebaceous complexes and hair follicles. The gland units are separated from each other by thin layers of connective tissue. Connective tissue also supports the walls of the ducts which are lined with stratified squamous epithelium and covered on the surface by cornified epithelium. The lower end of each duct opens into several sebaceous alveoli. The basal alveolar cells are small, but as they develop 
they become progressively enlarged, their nuclei shrink and disappear, and the cells break down into fatty detritus within the lumen of the duct. Many smaller undeveloped alveoli are present in the gland. The holocrine secretion collects in a common duct through whith also pass hairs from follicles in the deeper parts of the gland. The hairs have flattened curved surfaces, which is perhaps important in the movement of sebum out of the ducts (Glenn \& Gray, 1965).

The glandular area of the gland pad was measured in four adult gerbils of each sex, and was significantly larger in males $(33.2 \%)$ than in females $(16.2 \% ; P<0.05)$.

\section{Size and Growth}

Few subadult gerbils - those weighing less than $40 \mathrm{~g}$ (Prakash, 1971) - had discrete measurable mid-ventral glands with evidence of secretion, although all animals weighing more than $25 \mathrm{~g}$ had a bare mid-ventral patch of skin at the site of future gland development.

All measurements of gland size - length, width and area - were

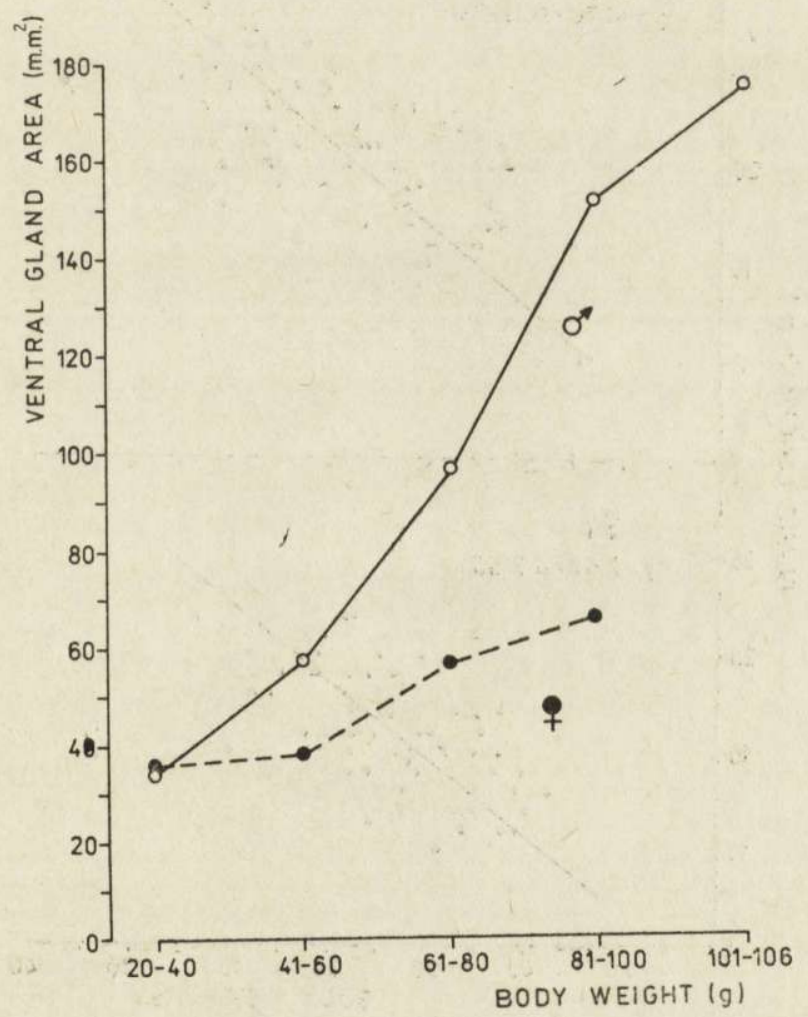

Fig. 2. Body weight and mid-ventral gland area of $M$. hurrianae. 
highly correlated with body weight and head and body length (Table 1; Figs 3 \& 4). Analysis of variance of gland area revealed significant effects of sex $\left(F_{1.133}=109.9, P<0.001\right)$, body weight class $\left(F_{1.333}=43.2\right.$, $P<0.001)$ and of their interaction $\left(F_{1.333}=7.8, P<0.01\right)$. Gland size did not differ between male and female subadults, but in all heavier weight

Table 1

Correlation coefficients $(r)$ of gland and body measurements of $M$. hurrianae. All correlations are significant at $P<0.01$, except this marked with*.

\begin{tabular}{|c|c|c|c|}
\hline & Correlation & $\begin{array}{c}\text { Correlation } \\
\text { Male }\end{array}$ & $\begin{array}{c}\text { coefficients }(r) \\
\text { Female }\end{array}$ \\
\hline Gland & length, $\mathrm{mm} /$ Body wt., $\mathrm{g}$ & 0.4665 & 0.4609 \\
\hline Gland & width, $\mathrm{mm} /$ Body wt., $\mathrm{g}$ & 0.5311 & 0.4327 \\
\hline Gland & area, $\mathrm{mm}^{2} /$ Body wt., g & 0.9163 & 0.6313 \\
\hline Gland & length, $\mathrm{mm} / \mathrm{head}$ and body length, $\mathrm{mm}$ & 0.3382 & 0.4708 \\
\hline Gland & width, $\mathrm{mm} /$ head and body length, $\mathrm{mm}$ & 0.5701 & 0.4663 \\
\hline Gland & area, $\mathrm{mm}^{2} /$ head and body length, $\mathrm{mm}$ & 0.3140 & $0.1706^{*}$ \\
\hline
\end{tabular}



Fig. 3. Scatter diagrams and regressions of gland length on body weight of M. hurrianae, 
classes males had glands both longer and of greater area than females (Table 2). Although male glands were similarly wider than those of females, the difference was only significant for gerbils weighing 81$100 \mathrm{~g}$, corresponding to 8-12 months of age (Table 2).

Gland size increased markedly in both males and females between body weights of $41-60 \mathrm{~g}$ and $61-80 \mathrm{~g}$, but thereafter increased signilicantly only in males (Table 2). Though gland area increased in roughly

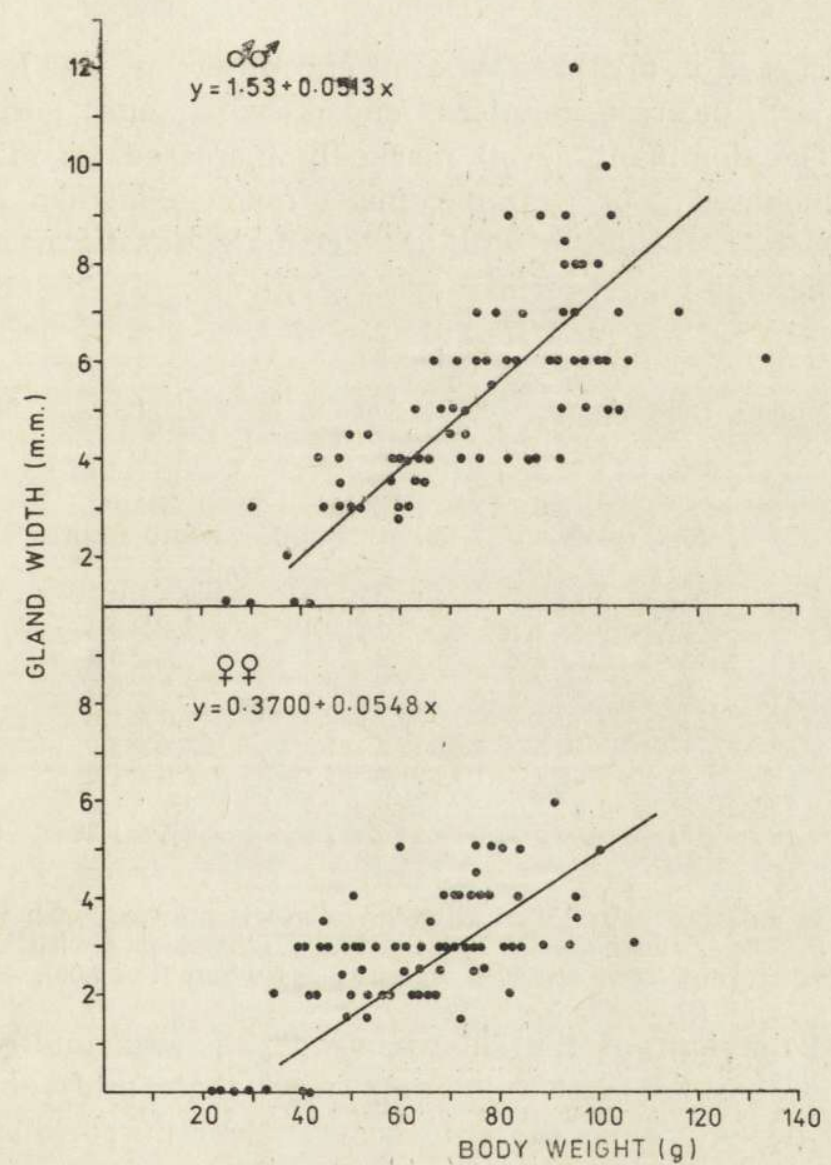

Fig. 4. Scatter diagrams and regressions of gland width on body weight of M. hurrianae.

linear proportion to body weight (Fig. 2), the rate of growth was considerably slower in females. When gland length and widths were regressed separately against body weights for each sex (Fig. 3 \& 4) and the regression coefficients for each measure compared between sexes, males differed from females in the slope of the regression of gland width on body weight $(P<0.05)$, but not in that of gland length. 


\section{Marking Behaviour}

In the $30 \mathrm{~min}$. marking tests, 37 out of 38 males but only 11 out of 28 females made at least one mark with their mid-ventral glands $\left(\chi^{2}=27.4, P<0.01\right)$. Marking frequency varied widely among individuals, though males (range 0-27 marks, median $=8$ ), marked more often $(P<0.01)$ than females (range $0-12$ marks, median $=0$ ), even when we consider only females which marked at least once (range 1-12 marks, median $=2$ ).

Fighting occurred in all three types of encounter but was less frequent among females; most encounters ended with one gerbil clearly "dominant". The dominant gerbil markedly increased its marking rate during the encounter. For example, males made a median of 6 marks in $30 \mathrm{~min}$. before an encounter with another male, but during the $15 \mathrm{~min}$. encounters, the dominant gerbils made a median of 19 marks while

Table 2

Gland measurements and body weights of male and female $M$. hurrianae (means \pm standard errors).

\begin{tabular}{|c|c|c|c|c|c|c|}
\hline $\begin{array}{l}\text { Body weight } \\
\text { class (g) }\end{array}$ & $\mathrm{N}$ & Sex & $\begin{array}{l}\text { Body } \\
\text { weight (g) }\end{array}$ & $\begin{array}{c}\text { Gland } \\
\text { length }(\mathrm{mm})\end{array}$ & $\begin{array}{c}\text { Gland } \\
\text { width }(\mathrm{mm})\end{array}$ & $\begin{array}{c}\text { Gland } \\
\text { area }\left(\mathrm{mm}^{2}\right)\end{array}$ \\
\hline $20-40$ & 2 & M & $34=$ & 13. & 2.5 & $34.0 \pm 13.5$ \\
\hline & 3 & & & & $2.7 \pm 0.4$ & $35.2 \pm 3.8$ \\
\hline $41-60$ & 15 & M & $51 \pm 4$ & $17.5 \pm 0.7^{2}$ & $3.6 \pm 0.9$ & $58.6 \pm 7.1^{1}$ \\
\hline & 24 & $\mathrm{~F}$ & $50 \pm 1$ & $14.2 \pm 0.4$ & $2.7 \pm 0.5$ & $39.1 \pm 4.1$ \\
\hline $61-80$ & 24 & M & $70 \pm 1$ & $0.4^{2,4}$ & $4.6 \pm 1.3$ & $97.6 \pm 7.7^{2,4}$ \\
\hline & 35 & $\mathrm{~F}$ & $70 \pm 2$ & $17.2 \pm 1.3^{3}$ & $3.3 \pm 0.5$ & $57.1 \pm 3.3^{2}$ \\
\hline $81-100$ & 26 & M & $92 \pm 3$ & $21.8 \pm 1.3^{2}$ & $6.6 \pm 1.0^{4,5}$ & $152.0 \pm 9.9^{2,4}$ \\
\hline & 12 & F & $87 \pm 2$ & $18.4 \pm 0.7$ & $3.7 \pm 0.3$ & $66.5 \pm 5.4$ \\
\hline $101-106$ & 10 & M & $104 \pm 1$ & $23.2 \pm 2.8$ & $7.5 \pm 1.3^{5}$ & $176.0 \pm 15.3$ \\
\hline
\end{tabular}

Significance between the sexes in same weight class is marked with ${ }^{1}$ for $P<0.05$ and with ${ }^{2}$ for $P<0.01$, and between consecutive weight classes with ${ }^{3}$ for $P<0.05$, for ${ }^{4} P<0.01$ ( ${ }^{5}$ different from $41-60 \mathrm{~g}$ weight class when $P<0.05$ ).

the marking behaviour of the submissive gerbils was totally inhibited.

In the field, gerbils most commonly used their mid-ventral glands to mark sand heaps around the entrances to their burrows and to mark the surface pathways from one burrow system to another. Both sexes used their scent glands for marking trails and burrow entrances. The difference in area of male $\left(90 \mathrm{~m}^{2}\right)$ and female $\left(155 \mathrm{~m}^{2}\right)$ home ranges was, however, the reverse of the sexual dimorphism in mid-ventral gland area (Fitzwater \& Prakash, 1969).

\section{DISCUSSION}

Mid-ventral sebaceous complexes are common not only within the genus Meriones but generally among members of the family Cricetidae 
(Quay \& Tomich, 1963; Thiessen \& Yahr, 1977). Nine of the 14 recognized species of Meriones (Nadler \& Lay, 1967) are known to have midventral glands which are longer and wider in males than in females (Sokolov \& Skurat, 1966; Thiessen \& Yahr, 1977). Both diurnal and nocturnal species have well developed glands.

The mid-ventral gland of $M$. hurrianae, is similar in many respects to that of $M$. unguiculatus. The histological structure of the gland specialised sebaceous units associated with hair follicles - differs little between the two species (Glenn \& Gray, 1965; Mitchell, 1965). In M. unguiculatus, the gland hypertrophies and becomes active at the onset of sexual maturity - about 4-16 weeks in males and 8-16 weeks in females (Glenn \& Gray, 1965; Mitchell, 1965). Few M. hurrianae weighing less than $40 \mathrm{~g}$ (about 8 weeks old) had observable glands unless they were sexually maturing (with scrotal testes or perforate vagina), whereas all gerbils of $40-60 \mathrm{~g}$ body weight (8-16 weeks old) had discrete, actively secreting glands. Gland size generally increased in both male and female $M$. hurrianae throughout the life of the animals. Sexual dimorphism in gland area was more marked among older gerbils primarily as a function of a sex difference in the rate of increase of gland width with body weight. Gland growth in female appeared to be constrained in ultimate width compared to males, perhaps by the different hormonal basis of gland integrity between sexes. The mid-ventral gland of $M$. unguiculatus is androgen dependent; gland growth and associated marking behaviour may be prompted in males by injection of testosterone and in females by injection of oestrogen and progesterone (Nyby \& Thiessen, 1971; Owen \& Thiessen, 1974). Oestrogen promotes gland regrowth both in castrated males and in ovariectomized females, but is less effective than testosterone in males, while testosterone is more effective than oestrogen in females (Nyby \& Thiessen, 1971; Thiessen \& Lindzey, 1970).

Scent marking of $M$. unguiculatus has been well documented in the laboratory; marking frequencies are higher in males than females, and in sociai encounters only the dominant gerbil continues to scent mark Thiessen, 1971; Owen \& Thiessen, 1974). Oestrogen promotes gland (Thiessen et al., 1973), M. libycus, M. crassus (Daly, 1977 and M. hurrianae. There are, however, few field observations of the use of the mid-ventral gland, and the functional significance of scent marks remains obscure (Daly, 1977). Ventral marking may be used to delimit territories (Thiessen \& Yahr, 1977), to promote time-sharing of habitat and resources (Daly \& Daly, 1975), to maintain colony cohesion (Roper \& Polioudakis, 1977) or to familiarise receptive females with potential mates (Daly, 1977). M. hurrianae defend only frequently used burrow 
areas within more extensive home ranges (Fitzwater \& Prakash, 1969). Ventral marking largely occurs on mounds of sand around burrow entrances, and along sandy trails between frequently used burrow systems. Its function may be to identify "home" as opposed to "foreign" habitat, and the constant remarking of familiar areas may result from the rapid disappearance of marks by wind action on the essentially unstable sandy habitat preferred by $M$. hurrianae.

Acknowledgements: We are grateful to Dr. H. S. Mann, Director of the Institute, for encouragement and for providing facilities. Thanks are due to A. N. Cowan and W. A. Hovard for histological advice and to Shri Doulat Goyal for statistical assistance. P. E. Cowan held a CSIRO (Australia) overseas postdoctoral studentship.

\section{REFERENCES}

1. Daly M., 1977: Some experimental tests of the functional significance of scent-marking by gerbils (Meriones unguiculatus). J. Comp. Physiol. Psychol., 91: $1082-1094$

2. Daly M. \& Daly S., 1975: Socio-ecology of Saharan gerbils, especially Meriones libysus. Mammalia, 39, 289-311.

3. Fitzwater W. D., Prakash I., 1969: Observations on the burrows, behaviour and home range of the Indian desert gerbil, Meriones hurrianae Jerdon. Mammalia, 33: $598-606$

4. Glenn. M. \& Gray J., 1965: Effect of various hormones on the growth and histology of the gerbil (Meriones unguiculatus) abdominal sebaceous gland pad. Endocrinology, 76: 1115-1123.

5. Mitchell O. G., 1965: Effect of castration and transplantation on ventral gland of the gerbil. Proc. Soc. exp. Biol. Med., 119: 953-955.

6. Nadler C. F. \& Lay D. M., 1967: Chromosomes of some species of Meriones (Mammalia: Rodentia). Z. Saugetierk., 32: 285-291.

7. Nyby J. \& Thiessen D. D., 1971: Singular and interactive effects of testosterone and estrogen on territorial marking in castrated male Mongolian gerbils (Meriones unguiculatus). Horm. Behav., 2: 279-285.

8. Owen K. \& Thiessen D. D., 1975: Estrogen and progesterone interaction in the regulation of scent marking in the female Mongolian gerbil (Meriones unguisulatus). Physiol. Behav., 12: 351-355.

9. Prakash I., 1971: Eco-toxicology and control of Indian desert gerbil, Meriones hurrianae Jerdon. VIII. Body weight, sex ratio and age structure. J. Bombay nat. Hist. Soc., 68: $717-725$.

10. Prakash I., 1973: Rodent control in the desert. Indian Fmg., 23: 41-43.

11. Prakash I., 1975: The population ecology of the rodents of the Rajasthan Desert, India. [In: »Rodents in desert environments« Ed. Prakash, I. \& Ghosh, P. K.]. Junk: $75-116$ The Hague.

12. Prakash I., Fitzwater W. D. \& Jain A. P., 1969: Toxic chemicals and baits for the control of two gerbils, Meriones hurrianae Jerdon and Tatera indica Hardwicke. J. Bombay nat. Hist. Soc., 66: 500-509.

13. Quay W. B. \& Tomich P. Q., 1963: A specialized midventral sebaceous glandular area in Rattus exulans. J. Mammal., 44: 537-542. 
14. Roper T. J. \& Polioudakis E., 1977: The behaviour of Mongolian gerbils in a semi-natural environment, with special reference to ventral marking, dominance, and sociability. Behaviour, 61: 207-237.

15. Sokolov W., Skurat L., 1966: A specific midventral gland in gerbils. Nature, Lond., 211: 544-545.

16. Thiessen D. D. \& Lindzey G., 1970: Territorial marking in the female Mongolian gerbil: short-term reactions to hormones. Horm Behav., 1: 157-160 .

17. Thiessen D. D., Wallace P., Yahr P., 1973: Comparative studies of glandular scent marking in Meriones tristami an Israeli gerbil. Horm. Behav., 4: 143-147.

18. Thiessen D. D. \& Yahr P., 1977: The gerbil in behavioural investigations. Austin and London: University of Texas Press.

Acrepted, September 20, 1980.

KUMARI S., COWAN P. E. I PRAKASH I.

GRUCZOE BRZUSZNY U MERIONES HURRIANAE

\section{Streszczenie}

Badano budowę histologiczną gruczolu brzusznego i jego rolę w znakowaniu zapachowym u Meriones hurrianae (Jerdon, 1867). Gruczol ten obejmuje zespoly powiększonych pęcherzyków lojowych typu holokrynowego, z których każdy ma własny przewód wyprowadzający. Wydzielina tych gruczołów zbiera się w dużym, wspólnym. przewodzie wyprowadzającym, skąd jest odkładana na różnych obiektach przez Meriones przy okazji charakterystycznego pocierania częścią brzuszną. Wielkość gruczołu jest skorelowana z ciężarem i długością ciała. Samce mają większe gruczoły niż samice, zarówno jeżeli chodzi o rozmiary absolutne, jak i względne, w stosunku do wielkości i ciężaru ciała (Tabela 1). Samce Meriones hurrianae więcej i częściej znakują teren zapachem, niż samice. Hierarchia socjalna stymuluje znakowanie przez osobnika dominującego, ale całkowicie hamuje ten behawior $\mathrm{u}$ osobnika podporządkowanego. 


\section{EXPLANATION OF PLATE III}

Plate III.

Fig. 1a. TS mid-ventral gland of M. hurrianae.

$\mathrm{S}=$ sectretion $; \mathrm{CD}=$ common ducts; $\mathrm{SA}=$ sebaceous alveoli; $\mathrm{VS}=$ ventral skin Scale bar $=0.5 \mathrm{~mm}$.

Fig. 1b. Sebaceous alveolar complex feeding into one common duct.

$\mathrm{CT}=$ connective tissue; $\mathrm{SE}=$ stratified epitheleum and cornified epitheleum. Other symbols as in Fig. 1a $(\times 125)$.

Fig. 1c. Hair follicle and hair shaft passing among sebaceous alveoli into common duct.

$\mathrm{H}=$ hair shaft; $\mathrm{HF}=$ hair follicle. Other symbols as in Fig. 1a $(\times 125)$. 




S. Kumari et al.

auctores phot. 